\title{
Towards an inclusive and gendered right to the city
}

In "The right to the city' Henri Lefebvre ([1968]1996) analysed the dialectic tension between the implosion of historic centres and the explosion of the urban beyond existing city boundaries under capitalist industrialization. The context of his intervention almost 50 years ago was the development of a national technocratic planning and the beginnings of gentrification in Paris' historic city centre. The city as a space occupied by productive labour, by oeuvres and festivities was being lost. The neo-capitalist city had replaced the historic core, which once represented the centre of decision-making according to the Western democratic imaginary, into a centre of consumption.

The right to the city is broadly conceived and draws together a set of related rights. In the words of Lefebvre:

Complemented by the right to difference and the right to information ... should modify, concretize and make more practical the rights of the citizen, an urban dweller (citadin) and user of multiple services. It would affirm, on the one hand, the right of users to make known their ideas on the space and time of their activities in the urban area; it would cover the right to the use of the centre, a privileged place, instead of being dispersed and stuck into ghettos (for workers, immigrants, the 'marginal' and even the 'privileged' (1996: 34).

The right to the city cannot be conceived simply as a visiting right or a call for a return to traditional cities. It can only be formulated as a transformed and renewed right to urban life for the whole of society and especially for those who inhabit it. The right to the city is open to all urban dwellers and not just citizens according to their social contract with the state (Lefebvre and Groupe de Navarrenx (1990/2003) . In conjunction with the right to difference and the right to information, the right to the city should work towards establishing a right for citizens as urban dwellers, especially with regards to their right to use of the centre, a privileged space compared to the ghettos for workers, immigrants, marginalised and for the wealthy who live in suburbs. The right to the city can be claimed by those who contribute to its daily production and social reproduction and are therefore empowered by it. The resurgence of Lefebvre's Right to the City is in part linked to the increasing recognition that the city provides a more relevant focus to explore social relations as well as socio-economic issues than the nation-state (Massey 2005).

Although a wealth of literature has been produced about the right to the city across the globe (Harvey 2012; Kipfer et al. 2013; Purcell 2002; Brenner and Schmid 2015; Sugranyes and Mathivet 2010), we argue that the right to the city as conceived by Lefebvre necessitates more than ever an engagement and re-contextualision given the fact that some of these concepts have changed, others have been revised, and importantly did not take into account gender.

Lefebvre ([1974] 1997, 2003) argued that spatial relations are continually produced and contested within cities, however feminist scholarship has pointed to Lefebvre's neglect of a specifically gendered perspective in his theorizations (Doderer 2003, Fenster 2005, Listerborn 2002, Simonsen 2005, Vacchelli 2014). In exploring Lefebvre's engagement with the body, Kirsten Simonsen observes that 'Lefebvre never seriously engaged with the 
production and practices of sexualized bodies and their relationship to social space'(2005:10) and how this particular perspective would represent a welcome contribution in order to sexualise Lefevbre's spatio-temporal bodies.

The question of how the right to the city is gendered cannot be separated from the debate on public and private spheres which has been at the core of feminist thinking in geography and in urban sociology for decades. Private and public are not neutral categories, they are loaded terms that conceal other gender-related hierarchical dichotomies solidified in the different discursive regimes of social reproduction and production, passive and active, unpaid work and breadwinner, body and mind, nature and culture. Famously, the North American urbanist Dolores Hayden (1982) problematised gender inequalities inscribed in the urban design of neighbourhoods, communities and the home. Urban design seemed to make the divisions between home and work even sharper; the failure in recognising domestic work as a productive activity meant that women with care responsibilities (of children, disabled people and the elderly) were excluded from economic life. In the UK, the work of the feminist urban geographers McDowell (1991), Mackenzie and Rose (1983) looked at the origin of the spatial division public vs private. They argued that factors that dovetailed into a consensus around the need for an 'urban solution' that upholds the values of a nuclear family-based on suburban domesticity include: concern from state agencies for the reproduction of labour and maintaining 'morality'; struggles of male dominated unions for a family wage; desires of both working-class and middle-class women for improved conditions for domestic labour. This narrative prevailed from the mid- twentieth century.

In her ground-breaking book The Sphinx in the City Elisabeth Wilson (1992) argues that feminist scholarship concerned with cities was in danger of perpetuating anti-urbanism already prevalent in much mainstream urban theory and practice (Bondi and Rose 2003) where the city was depicted as a place that constrains, disadvantages and oppresses women. Wilson condemned much feminist writing as 'hostile to the city', and further argued that 'recent feminist contributions to the discussion of urban problems have tended to restrict themselves narrowly to issues of safety, welfare and protection' (Wilson, 1992: 10) instead of asserting women's rights to the risks of the city recognising that the city has consistently emancipated women more than rural life or suburban domesticity ever has. On the contrary Wilson states that cities enable women to escape the constraints of normative expectations by widening their horizons. We see urban space as constructed by gender, class and race difference where minorities are disadvantaged and representationally excluded, as with Muslims in Paris (see Hancock and Ouamrane) or migrant women in many cities, such as Buenos Aires (see Bastia in this SI) and Zurich (see Chau, Pelzelmayer and Schwiter in this SI)

The 1990s marked a shift in feminist urban studies where public space stops being interpreted as a place of fear and starts being understood as a space for potential emancipation (Bondi and Rose 2003, Terlinden 2003). An increased awareness of the differences between women in terms of class, age, education, ethnicity and of the oppressive power dynamics between women enabled the development of critical perspectives on how different social identities were inscribed in public space and on the implications of these inclusions and exclusions in terms of citizenship (Bondi and Rose 2003). Moreover, studies at the intersection between gender, class and the urban form had failed to problematize issues of sexuality and heterosexual nuclear families were assumed to be the norm. Work looking at LGBT communities as agents of urban change and everyday life of lesbian women and their exclusion for the public realm (Lauria and Knopp 1985, Valentine 1989, 1993) highlighted 
the need for more inclusive and complex understanding of citizenship, implying that modern Western urban forms are simultaneously repressive of and provide a laboratory of possibilities for counter-hegemonic sexual relations (Knopp 1992). Public space, its use and the visions of society it entails were at the centre of urban enquiry so was the mutual constitution of gender and space in feminist writings (Mackenzie 1988, Walkovitz 1992).

Feminist critiques of women's partial inclusion in citizenship (Lister 1990; Pateman 1988) stemmed from the way women had been incorporated into the polity and the attempt to anchor their socio-economic and political participation in the practices and spaces of everyday life (Smith 1998). Fundamentally these critiques challenged the demarcation of the private and the public, which came together through everyday practices and called for the opening up of new spaces as the basis of claims making and social movements in the city (Werkele 2000). All spaces had the potential to be political. These writings have been particularly fruitful for overcoming the polarity between viewing urban space as necessarily disabling or enabling for women and consider the complexities of this debate (Bondi and Rose 2003).

Conceptualising the right to the city in a gendered perspective is particularly important today in the aftermath of the economic crisis as the rights of women have been made less visible though combined processes of austerity urbanism, welfare reform and urban planning geared towards capital accumulation. According to Shami Chakrabarti (2017), austerity measures in the UK disproportionally hit women and migrant women as evident from the following figures and facts: $86 \%$ of austerity cuts has fallen on women; women earn less, rely more on benefits and are more likely to be single parents so budget cuts affect them disproportionately; non-white women are discriminated by their gender, ethnicity and income; precarity of casual and gig economy affects women more as they are more represented in part-time and voluntary work ( $42 \%$ women works part time compared to $14 \%$ of men). Women bear the brunt of cuts in work benefits and public expenditure.

The cutbacks and/or the failure to expand public provision in welfare has led to an increasing recourse to female migrant labour. Disproportionately, women have migrated to large cities in the Global North and South to perform social reproductive work -domestic and care workboth in the household and care homes (Kofman and Raghuram 2015; Sassen 2000). Through their work in households, many migrant women remain invisible in public spaces. Migrants and refugees, in particular face a wide range of barriers to a dignified life when faced with de-skilling, unprotected labour, gender violence at a time when institutional support is diminishing and citizenship is diminishing and citizenship is becoming a central factor for the eligibility in access to services.

Yet some migrant women have contested their marginal situation through use of formal mechanisms such as occupying public spaces and resorting to legal systems to improve their working conditions and access to resources and the get the value of their work recognised (see Chau, Pelzelmayer and Schwiter on Zurich in this SI). A range of means are deployed in ensuring civic participation through different kinds of spaces, such as voluntary organisations which allows migrant women to enact bottom-up civic participation and transform it from below (see Vacchelli and Peyrefitte in this SI) and in this way shifting from a/topia or not having a space or being denied it to topia. Migrant women, as in Buenos Aires, while participating in grassroots movements, may not see their role in the same way as men. Rather than view it as political they have tended to treat as solely contributing to well being but effectively do put forward alternatives for women to be free from gendered violence (see Bastia in this SI). 
The right to the city and its diverse spaces may also be claimed by minority women. Hancock and Ouamrane highlight the discrimination Muslim, especially veiled women, face in peripheral urban spaces and their attempts to claim the right to domesticate symbolic central areas of Paris. Activism can be complex and multiple, daily and a one time event, and bring people together. Different individuals, such as migrants, refugees, the homeless and neighbourhood residents, themselves marginalised Mizrachi women, encounter each other in the struggle for the right to the city in Tel Aviv (see Misgav and Fenster in this SI).

The reconfiguration of the right to the city, as in the case of Rotterdam (see paper by van den Berg and Chevalier), away from its old male working class industrial heritage to one of consumption and leisure through using gendered repertoires to manage its macho images and present a more feminised space designed for consumption. At the same time in many cities, redevelopment has involved cleansing of cities whereby those with weak economic positions and dependent on welfare, such as the single mothers, have been displaced and pushed out of the centre where they have established social networks out of the city (see Watt's paper in this SI). For non-urban inhabitants, the demand for the right to the city may emanate from those demanding access to its resources which they do not have in the rural areas in which they live (see Fabula and Timar's on Hungary in this SI). This hits those with disabilities and reduced mobility the hardest.

This Special Issue is mainly concerned with the ways in which on-going social practices in cities reinforce gendered and other intersectional hierarchies. The idea for this Special Issue emerged at the International Geographical Union (IGU) pre-conference organised by the IGU Gender Commission in Milwaukee in 2015. Most papers were presented during two sessions entitled Gendered right to the city, migration and citizenship that we organised to engage feminist geographers in this important debate after almost 50 years from its onset. In this analysis, the work of Henri Lefebvre has been read by feminist scholars in urban contexts beyond the Anglo-American locus of knowledge production, including Argentina, France, Israel, Hungary, the Netherlands, and Switzerland. In the reading of Lefebvre, the gendered right to the city aims at widening the idea of citizenship to encompass a bundle of social, political and economic rights such as participation, access to resources, right to housing and welfare, having one's work paid for and recognised, and one's voice heard and not silenced.

One key idea that runs through the articles is that exploring gendered rights to the city should be envisaged as an articulation between gender, ethnicity, race and class. In other words, gendered rights to the city are determined at the intersection with other social categories (Yuval Davis 2006) and social divisions. Anthias (1998: 530) further highlights the importance of looking at what happens at the local level of the city when dealing with question of social divisions as parameters of social inequality and exclusion.

\section{References}

Anthias, F., 1998. Rethinking social divisions: some notes towards a theoretical framework. The Sociological Review, 46(3), pp.505-535.

Bondi, L. \& D. Rose (2003) Constructing gender, constructing the urban: A review of Anglo-American feminist urban geography, Gender, Place \& Culture: A Journal of Feminist Geography, 10:3, 229-245. 
Brenner, N. and Schmid, C., 2015. Towards a new epistemology of the urban?. City, 19(2-3), pp.151-182.

Buckingham, S. 2010. Examining the right to the city from a gender perpsective', A. Sungraynes, and C.Mathivet (eds) Cities For All. Proposals and experiences towards the right to the city. Santiago: Habitat International Coalition, HIC.

Chakrabarti, S. 2017 Austerity is a feminist issue', The Guardian $8^{\text {th }}$ March

Doderer, Y.P., 2003. Urbane Praktiken: Strategien und Raumproduktionen feministischer Frauenöffentlichkeit. Münster: Verlagshaus Monsenstein und Vannerdat.

Fenster, T. 2005. The right to the gendered city: different formations of belonging in everyday life' Journal of Gender Studies 14(3); 217-31.

Harvey, D. 2012. Rebel Cities. From the Right to the City to the Urban Revolution. London and New York: Verso Press.

Hayden, D., 1982. The grand domestic revolution: A history of feminist designs for American homes, neighborhoods, and cities. mit Press.

Kipfer, S., P. Saberi, and T. Wieditz. 2013. Henri Lefebvre. Progress in Human Geography $37: 115-34$.

Knopp, L., 1992. Sexuality and the spatial dynamics of capitalism. Environment and Planning D: Society and Space, 10(6), pp.651-669.

Kofman, E. and P. Raghuram. 2015. Gendered Migrations and Global Social Reproduction, Palgrave Macmillan

Lauria, M. and Knopp, L., 1985. Toward an analysis of the role of gay communities in the urban renaissance. Urban geography, 6(2), pp.152-169.

Lefebvre, H. 1968/1996. Writings on Cities, edited and translated E. Kofman and E. Lebas, Blackwell.

Lefebvre and Groupe de Navarrenx 1990/2003 From the social pact to the contract of citizenship. In Henri Lefebvre. Key Writings. Eds. and Trans. S. Elden, E. Lebas and E. Kofman, Continuum, pp. 238-54.

Lefebvre, H., 1974/1991. The Production of Space, translated by D. Nicholson-Smith. Blackwell. 
Lefebvre, H., 2003. The urban revolution. U of Minnesota Press.

Lister, R., 1990. Women, economic dependency and citizenship. Journal of Social Policy, 19(4), pp.445-467.

Listerborn, C., 2002. Understanding the Geography or Women's Fear: Toward a Reconceptualization or Fear and Space. Subjectivities, knowledges, and feminist geographies: The subjects and ethics of social research, p.34.

Massey, D., 2005. For Space Sage. Thousand Oaks CA.

McDowell, L., 1991. The baby and the bath water: diversity, deconstruction and feminist theory in geography. Geoforum, 22(2), pp.123-133.

Mackenzie, S., 1988. Balancing our space and time: the impact of women's organistion on the British city, 1920-1980. In Women in cities (pp. 41-60). Macmillan Education UK.

MacKenzie, S. and D.Rose (1983) Mackenzie, S. and Rose, D., 1983. Industrial change, the domestic economy and home life. Redundant spaces in cities and regions, pp.155-200.

Pateman, C. 1988. The Sexual Contract, Polity/

Purcell, M. 2002.Excavating Lefebvre: the right to the city and its urban politics of the inhabitant. Geojournal 58: 99-108.

Sassen, S. 2000 'The global city: Strategic site/new frontier. American Studies 41(2-3), 7995

Simonsen, K., 2005: Bodies, sensations, space and time: the contribution from Henri Lefebvre. Geogr. Ann., 87 B (1): 1-14.

Smith, D. 1998 The Everyday World as Problematic. A feminist sociology, Northeastern University Press.

Sugranyes, A. and C. Mathivet. Eds. 2010.Cities for All. Proposals and experiences towards the right to the city. Santiago: Habitat International Coalition, HIC.

Terlinden, U., 2003. Public Man and Private Woman: Discourse and Practice in Western Societies. City and Gender: International Discourse on Gender, Urbanism and Architecture, pp.41-56. 
Walkowitz, J.R., 1900. City of Dreadful Delight: Narratives of Sexual Danger in LateVictorian London (Chicago, 1992). WalkowitzCity of Dreadful Delight: Narratives of Sexual Danger in Late-Victorian London1992.

Werkele, G. 2000. Women's rights to the city: gendered spaces of a pluralistic citizenship', In E. Isin (ed) Democracy, Citizenship and the Global City, Routledge, pp.203-17.

Wilson, E., 1992. The sphinx in the city: Urban life, the control of disorder, and women. Univ of California Press.

Vacchelli, E., 2014. Gender and the city: intergenerational spatial practices and women's collective action in Milan. Les cahiers du CEDREF. Centre d'enseignement, d'études et de recherches pour les études féministes, (21).

Valentine, G., 1989. The geography of women's fear. Area, pp.385-390.

Valentine, G., 1993. Negotiating and managing multiple sexual identities: lesbian time-space strategies. Transactions of the Institute of British Geographers, pp.237-248.

Yuval-Davis, N., 2006. Intersectionality and feminist politics. European Journal of Women's Studies, 13(3), pp.193-209. 